\title{
News analysis
}

\section{Ukraine: in the club with L\&M}

A frequent theme in tobacco advertising in the countries of Central and Eastern Europe and the former Soviet Union is to exploit the fact, real or perceived, that people are now part of a wider community of nations. "Test the West" was an early example from the German firm Reemtsma: an invitation to try the "superior" cigarettes that had been the exclusive preserve of western Europeans but now, thanks to democratisation, were at last available to all. Some promotions even gave citizens of the new market economies a whole new pack of western cigarettes in exchange for their old, state manufactured cigarettes. These were promptly thrown in a bin to rub in the fact that their "quality" was so inferior compared to the new brand that incineration, without inhalation by their recent owner, was all they were fit for.

A recent campaign for the Philip Morris (PM) brand LEM in the Ukraine took a more passive line, but played up the new, much wider personal horizons of Ukrainian citizens, extending way beyond the old FSU, not just into western Europe, but right around what PM undoubtedly would have referred to in the past as "the free world". Under a caption proclaiming "Flavour that unites the world", the ads invited potential LEM smokers to consider themselves linked together, as if by membership of an exclusive club, with other potential lung cancer and heart disease patients in cities such as Stockholm, Bangkok, and Brasilia. Ironically, all those are capital cities of countries with strong tobacco control laws, whose citizens therefore are denied any link with the Ukrainian people's opportunity to see absurd ads promoting a product likely to kill about a half of those who use it throughout adult life.

In times of optimism, family themes work well, too, as people feel more confident about bringing new generations into the world, just as tobacco companies feel more confident about

All articles written by David Simpson unless otherwise attributed. Ideas and items for News Analysis should be sent to David Simpson at the address given on the inside front cover. recruiting them as new customers. So it was that PM's Ukrainian advertisers ran a picture of a happy couple who are clearly expecting a new addition to the family. Above the slogan: "Connected to you - Luxembourg", the man was not only connected to the woman by planting an intimate caress, even a love-bite, on the cheek of his kittenish partner, but also, by his right hand, to the unborn child in the woman's abdomen. Neither model was visibly smoking, though strangely, the man held his left hand in smoking posture and seemed to have injured the index finger of his right hand, possibly from a cigarette burn, or a prior bite that went astray.

Visitors from The Netherlands were as shocked as Ukrainian health advocates and telephoned PM's Dutch office when they got home, asking whether the company encouraged smoking during pregnancy. The local office immediately contacted PM's regional headquarters in Lausanne, Switzerland. A leading Dutch newspaper ran the story, which was duly picked up by radio stations, and back in the Ukraine, local health advocates worked the press and broadcasting media. Shortly afterwards, while refusing to return journalists' telephone calls, PM replaced the images with other LEM ads without pregnant models.

In a sickening example of the international tobacco industry's "We've changed!" image rehabilitation strategy, PM last year deluged the Ukraine

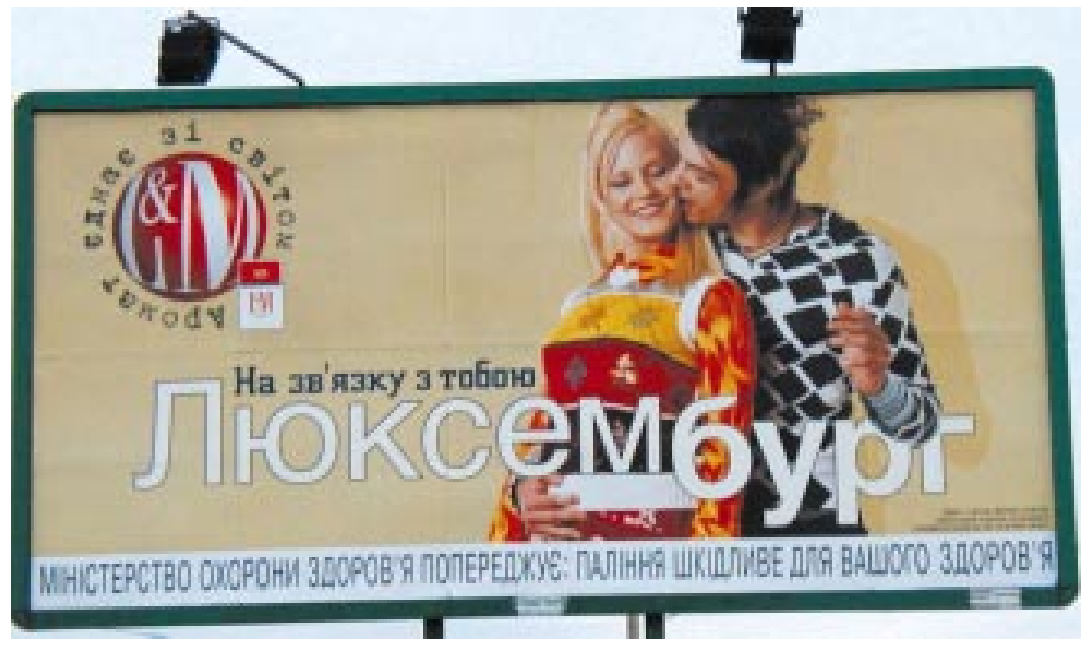

Ukrainian advertisement for the Philip Morris brand L\&M, seemingly encouraging smoking during pregnancy.

with "health education" leaflets warning pregnant women against smoking. The appearance of the pregnant woman billboards is just another instance of a perennial truth about tobacco companies: however glossy the public relations tricks, the ideals they try to persuade the world they have adopted bear absolutely no resemblance to the activities of their marketing departments, where it's business as usual.

\section{Thailand: how to stop a canal being used to launder images}

Bangkok has been called the Venice of the East on account of its numerous canals criss-crossing the metropolis with their famous floating markets. One of the canals-the Saen Saebremains a significant artery for transport and the alleviation of flooding, and in former times it was also a centre for marine commerce. Many people used the $72 \mathrm{~km}$ canal to travel to and from Bangkok to Chacoengsao Province in the East. But the pleasant way of life on the Saen Saeb canal has changed. Now it buzzes with mosquitoes and other insects, especially at night, and travel on it is no longer leisurely because boats speed along to get through the polluted waters as quickly as possible.

All these culminated in the Keep Saen Saeb Canal Clean Project, created 
by the NATION Multimedia Group which owns several print and electronic (TV) media, including the second most popular English language daily newspaper and Bangkok Business, the most popular Thai language business daily. The project was publicised in these newspapers over four weeks last autumn, with half page advertisements showing the logos of its three sponsors. The principal sponsor was British American Tobacco (BAT). An ad in early October publicised Canal Lovers Day festival, when the Bangkok governor received the funds donated by sponsors, including BAT's local manager. Publicity of the event included television coverage and billboards along the sides of the canal. The organisers said the publicity would run right though until the end of March 2002.

Dr Hatai Chitanondh, president of the Thailand Health Promotion Institute, was appalled by what he described as "this blood-stained donation to charity", and set about compiling a dossier of all the worst aspects of BAT's operations. The result, a 12 page document, Facts about BAT, aimed to inform ordinary people, in clear and simple language, about the real nature of tobacco companieshow they know that cigarettes are addictive, manipulating nicotine to hook consumers, sabotaging tobacco control in developing countries, their contempt of the World Health Organization, their targeting of youth and women, price collusion, smuggling, and image laundering-with all the key points illustrated from internal industry documents, many of them from BAT. Dr Chitanondh sent the dossier to the chairman of the NATION Multimedia Group asking him to reconsider BAT's sponsorship. The result? The NATION Multimedia Group promptly discontinued the publicity and handed over the funds to the districts along the Saen Saeb canal, to continue the good work without any more fanfare.

\section{Germany: bogus polls and the Euro-pain syndrome}

More news from Germany, tobacco rent-a-nation of the European Union (EU), where the fight by industry interests against relatively small health forces continues to produce some extraordinary anomalies in a country so long at the forefront of technological progress. In December,

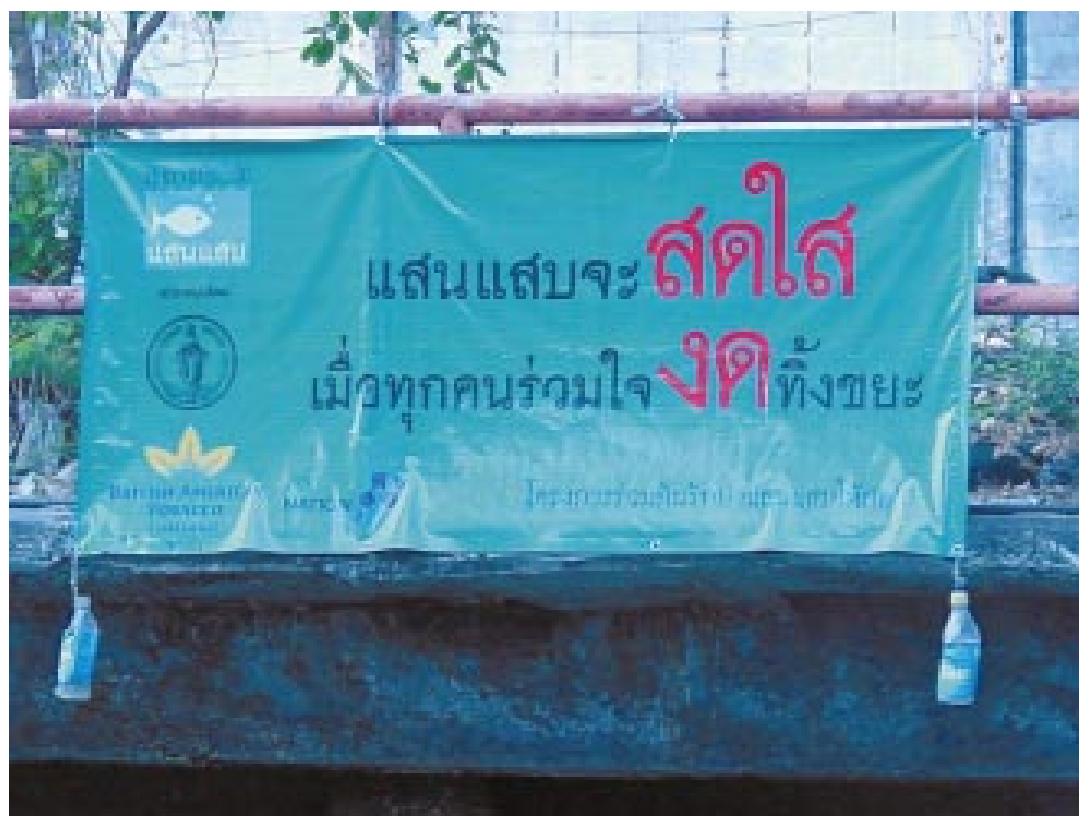

Billboard alongside the Saen Saeb canal in Bangkok, featuring the British American Tobacco logo. Although BAT were the main sponsors of the Keep Saen Saeb Canal Clean Project, the company's funding was described by one Thai health official as "this blood-stained donation to charity", and the publicity was promptly stopped.

the German tobacco trade journal Tabakzeitung gleefully announced the results of a poll carried out last year, apparently showing that only $6 \%$ of adult Germans backed a tobacco advertising ban, whereas three times that number had backed one just a year earlier. It said almost half of Germans did not want to see any changes to advertising regulations, a dramatic increase in acceptance since 1999, when only $30 \%$ shared this opinion.

German health advocates tried to obtain the questionnaire used in the poll, but the reputable research company declined on the grounds of client confidentiality, confirming that it had been privately commissioned, presumably by the tobacco industry.

The tobacco industry may have hoped that the new poll findings would help its case at an important World Health Organization interministerial conference on tobacco held in Warsaw in February. Perhaps it did indeed provide further justification for the German government's already well established hostility to an ad ban, though the reason cited by the German delegation in Warsaw, which kept pulling furiously on the handbrake as other, exasperated nations pressed for a strong 'Warsaw Declaration for a Tobacco-Free Europe', was that it would violate Germany's constitution.

Health advocates say several large Mercedes trucks could be driven side by side through the gaps in this argument. More to the point, they note that as long ago as 1997 the German health ministry included questions on attitudes to a tobacco advertising ban in a regular health ministry survey of a representative sample of some 8000 German residents aged 18-59 years. Compared to the new poll in the industry journal, the results told a very different story. The majority in the health ministry survey, around 6 out of 10, favoured an ad ban. Furthermore, a survey commissioned by a television station five years ago, and conducted by the same researchers used by Tabakzeitung, found that even then, two thirds of adults favoured an ad ban.

Since 1997, there has been a significant increase in publicity about the disastrous toll of smoking on German people's health, and about outrageous tobacco industry activities to maintain business as usual; so, if anything, it might be expected that approval for anti-tobacco measures would have increased. Unfortunately, and perhaps not accidentally, when the health ministry repeated its survey recently, tobacco advertising was not among the topics addressed in the attitudinal questions. How much longer the government favours tobacco advertising over the interests of public health remains to be seen; but those returning to Bonn surely cannot have failed to report the desperate sense of frustration generated in Warsaw by their government's stubborn and unwavering loyalty to the tobacco industry. 


\section{India: bravery awards update}

As noted in our last edition, an outrageous cigarette promotion by Philip Morris in India links its Red \& White cigarette brand with bravery and other forms of selfless service to humanity through an annual bravery award. Operating at state level, the scheme maximises regional press coverage, with flurries of positive associations when the winners' details are announced. In all the pomp and glitter of the judging and awards processes, it seems that no-one sits back to consider whether some awards might not just have a touch of irony that could come back to haunt the sponsors. In January, for example, did it not occur to anyone at PM's publicity machine that a link with dead bodies might not be quite the association the company was trying to cultivate? For in the state of Maharastra, of which Mumbai (formerly known as Bombay) is the capital, one of the winners was $\mathrm{Mr}$ Chandrakant Mehar, 45, whose gold medal in the "Acts of Social Courage" category was for getting dead bodies donated to medical research.

Apparently Mr Mehar, a milk seller by trade, believes so passionately that medical schools should have all the dead bodies they need for teaching and research that he has spent all his spare time over the past 17 years convincing people to donate their bodies to the medical college of Nagpur, in his home state. By the time his citation had been submitted to the 10th Red $\delta$ White Bravery Awards judges, the bodies of around 200 people had already been passed to the college as a result of his efforts, and he had persuaded another thousand or so who are still alive to pledge that theirs will follow in due course.

Perhaps it is all part of a highly practical view of man's life cycle, originally developed several millennia ago in some little known corner of India's long tradition of philosophy, and imbued with a particularly stoical acceptance of life's many sufferings. In India, these include a massive amount of cancer and other diseases caused by tobacco, resulting in at least 600000 premature deaths each year, possibly as many as a million. The theory might go like this: cigarettes kill about half their lifetime users before their time, thereby increasing the potential availability of dead bodies for research. This in turn helps train more doctors and scientists, who produce new advances in the prevention and cure of disease,

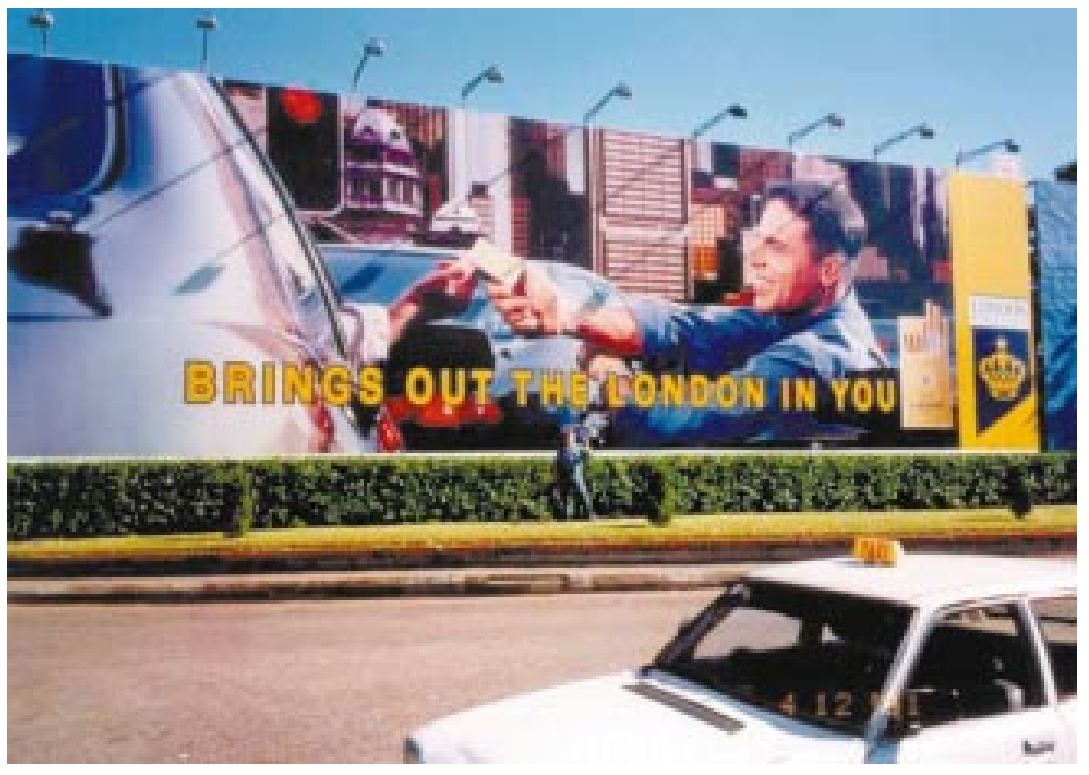

Despite Myanmar still being a comparatively closed society, British American Tobacco seems to have had no trouble moving in and putting up this giant billboard in the capital, Rangoon.

thus causing more people to live longer. This means that more cigarettes are sold, which kill about half their lifetime users ... A fantasy? Of course, but so is the association of cigarettes with bravery and social service. One inescapable reality, however, is that this particular prize has inadvertently, if appropriately and inextricably, associated Philip Morris and its Red \& White cigarettes with the fate of so many of its users.

\section{The company they keep}

The public relations company Hill \& Knowlton, which has offices in most corners of the globe, seems to like controversial clients. In the USA, for example, it serves the Teamsters Union, the Church of Scientology, and Mr Ken Lay of Enron, the energy company whose record breaking bankruptcy was accompanied by allegations of dishonest business practices on a truly heroic scale. So it must be heartening for them that in South Africa, they look after the Tobacco Institute. All over the world: nice people to do business with.

\section{USA: getting to organised labour}

Although significant gains have been made in reducing overall smoking in the USA, $36 \%$ of craft workers and labourers and $32 \%$ of service workers continue to smoke, while the rate is down to $21 \%$ among white collar workers. As labour unions often represent blue collar workers, the Organized Labor and Tobacco Control Network (OLTCN) has been formed to reduce class based health disparities in the USA due to high levels of tobacco use and exposure to second hand smoke among working people and their families.

OLTCN, a joint programme between the Dana-Farber Cancer Institute and the University of Massachusetts Lowell, engages in a number of activities: from research on how unions can tailor smoking cessation programmes for their members, to consultation on how to create partnerships between the labour and tobacco control movements. In addition, OLTCN actively engages in educational and networking efforts to bring the two movements together. Initial funding has been provided by the American Legacy Foundation.

Specific activities of OLTCN include a pilot project with the eastern Massachusetts branch of the Ironworkers Union (AFL-CIO) that aims to develop and incorporate a smoking cessation programme for young workers in the union's apprenticeship programme. OLTCN is also preparing to conduct a series of interviews in the USA with key union and tobacco control leaders. OLTCN plans to publish the results of these interviews, as well as more in-depth case studies of specific union-tobacco control interaction, within the next year.

GREG DELAURIER splash5@rcn.com 

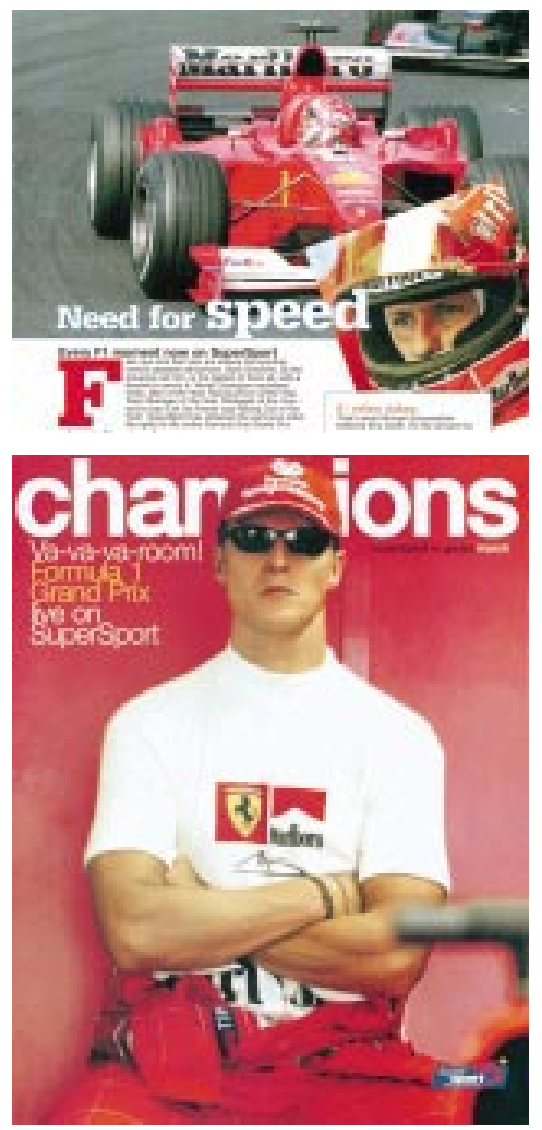

South Africa: some of the 26 images promoting Marlboro cigarettes in the March 2002 edition of a satellite television programme guide. Health advocates have made official complaints about the guide for breaching the country's strict tobacco advertising ban.

\section{USA: continuing battles over "acceptable" air quality standards}

The American Society of Heating, Refrigerating and Air-Conditioning Engineers (ASHRAE) is an international organisation of more than 55000 members with chapters throughout the world. ASHRAE develops standards that "set uniform methods of testing and rating equipment and establish accepted practices for the HVAC\&R (Heating, Ventilation, Air Conditioning and Refrigeration) industry worldwide, such as the design of energy efficient buildings" (www.ashrae.org). ASHRAE then submits its standards to the American National Standards Institute (ANSI) for endorsement as an American standard. Furthermore, ASHRAE standards are also adopted by several other international standards setting organisations as their own national standards, giving ASHRAE a reach well beyond the USA.
The tobacco industry, for the past 20 years, has been heavily involved with ASHRAE in an attempt to influence the development of Standard 62Ventilation for Acceptable Indoor Air Quality. The industry was successful until recently-Standard 62 determined ventilation rates to accommodate a "moderate" amount of smoking and ignored the health effects of second hand smoking. However, despite the tobacco industry's overt and covert manoeuverings, the latest version of the standard, 62-1999, determines ventilation rates based on the premise that there will be no smoking indoors, the only exceptions being casinos, bars, and cocktail lounges. Currently, there are no standards that recommend ventilation rates if smoking is allowed in places such as restaurants or bowling alleys. To comply with the standard, these places have to be entirely smoke-free. Furthermore, standard 62-1999 declares that tobacco smoke is a known carcinogen. In response to the standard, the tobacco industry rallied its allies in the hospitality industry, who began lobbying ASHRAE to develop a separate ventilation standard for the hospitality industry, as if workers and patrons in these venues do not deserve acceptable indoor air quality.

On the health side, many denounced the industry's obvious influence. The American Heart Association wrote a strongly worded letter to ASHRAE urging it not to "contribute to the body count" by supporting the unfounded claim by the tobacco industry that ventilation can protect non-smokers from second hand tobacco smoke. Professor Stanton Glantz, through the TobaccoScam project (to educate the hospitality industry about tobacco industry manipulation), attempted to run an ad in the ASHRAE Journal denouncing the tobacco industry influence over ASHRAE and ASHRAE's apparent acceptance of that influence. The journal refused to run the ad, which was timed to coincide with the Winter meeting issue (January), when a symposium debating the need for a separate standard was being held. With one exception, the symposium presenters were consultants and allies of the tobacco industry, with none of the invited participants being from a recognised health group. Glantz then ran the ad in another trade publication, Engineered Systems, under the introductory heading: "This is the ad that ASHRAE refused to run."

The ad created quite a stir for controversy-shy ASHRAE. The society's

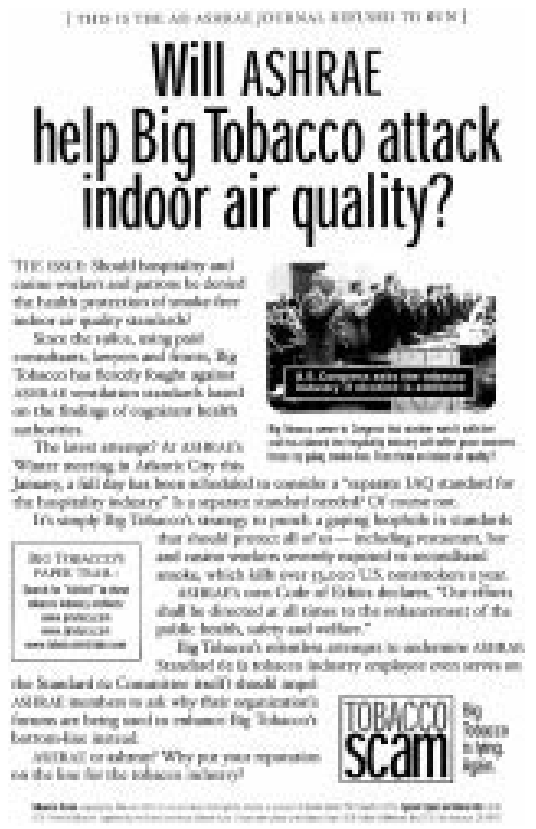

Advertisement denouncing the tobacco industry's influence over ASHRAE (American Society of Heating, Refrigerating and Air-Conditioning Engineers), which the ASHRAE Journal refused to run.

president, William J Coad, wrote a commentary in the February issue of the journal; ironically, while misrepresenting the ad, he implied that despite years of tobacco industry influence, ASHRAE did not cave in under pressure from interests groups. More revealing was Coad's implication that there were still doubts about the harmful effects of second hand smoke and the inability of ventilation systems to eliminate the hazards it causes. With a blizzard of letters sent to the ASHRAE Journal, the saga continues. Until recently, it has been dominated by the tobacco industry, but tobacco control advocates are now looking to other influential health groups to become involved, to ensure that the top priority of indoor air standards is the protection of people's health, not the continued prosperity of the tobacco industry.

STELLA AGUINAGA BIALOUS Center for Tobacco Control Research and Education, University of California San Francisco, USA stella@bialous.com

\section{Yugoslavia: jobs or health?}

Belgrade has become a more colourful city since the overthrow of the Milosovec regime. Eye catching billboards throughout the city proclaim slogans such as "Freedom always", "I choose", and "The taste of freedom". But these 

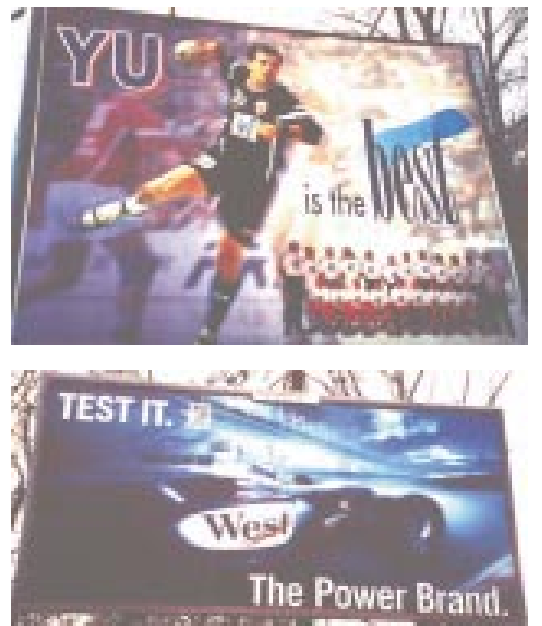

Billboards like these are ubiquitous in Belgrade. The ad for West, produced by the German company Reemtsma, exploits the brand's Formula One sponsorship, while Best, produced by domestic manufacturer DIN and showing notable similarities in design, makes the most of sponsoring Yugoslavia's internationally renowned handball team. Photo credit: Gordana Popovic.

words do not refer to the new political freedom. Instead they are sound bites from the international tobacco industry.

Under Milosevic, 90\% of cigarettes sold were smuggled into Yugoslavia, with individuals closely linked to the former regime playing an active part. The two domestic tobacco companies, which in theory held a monopoly, accounted for the remaining $10 \%$. Now illegal sales have fallen to $30 \%$ of the total and the street vendors, perched on their crates of cigarettes, are out of work.

Lured by prospects of scarce inward investment, the new government has welcomed the international tobacco industry. Faced with an unemployment rate of $40 \%$, offers of factories each promising 200-500 jobs become very attractive. Proposals are flooding in, from the UK and USA, from Greece and Cyprus, and from Croatia and Bulgaria. The industry is also offering investment in tobacco cultivation, which, it claims, would provide even more jobs. Inevitably, the cost of entry is falling as local politicians compete to attract investments to their own towns. At the same time, deaths from tobacco related diseases are rising rapidly.

So Yugoslavia faces a dilemma: jobs or health? But this is not just a matter for Yugoslavia. The Yugoslav coast is an ideal base for the speedboats that have, for years, been smuggling cigarettes from Montenegro into Italy, and onwards through the European Union. It remains to be seen whether the recent affirmation of an antismuggling position by certain tobacco companies is more than cosmetic.

VUK STAMBOLOVIC Medical Faculty, University of Belgrade, Federal Republic of Yugoslavia vstambol@infosky.net

MARTIN MCKEE

London School of Hygiene and Tropical Medicine, UK martin.mckee@Ishtm.ac.uk

\section{0 years on}

March 7 saw the 40th anniversary of the publication of Smoking and health, the report that could be said to have started it all off. The pioneering epidemiological work of the late Austin Bradford Hill and his younger collaborator Dr (now Sir) Richard Doll, and
American colleagues such as Wynder and Hammond, formed the scientific foundations on which the first report of the Royal College of Physicians of London was constructed. That review of the then relatively new but rapidly expanding body of evidence of the devastation we now know smoking causes to health, led directly to the first US Surgeon General's report on the subject.

It was appropriate that Sir Richard, now in his 90th year (but still working a fuller week than many people half a dozen decades his junior), was at the college for the launch of a short report aptly entitled Forty fatal years. Published jointly with Action on Smoking and Health, the campaigning body set up by the college immediately after its second smoking report in 1971, it catalogues what on the one hand can be regarded as among the most important advances in public health in the history of the UK, the USA, and many other industrialised countries, but on the other hand, when viewed in global terms, may come to be regarded as the most scandalous waste of human life ever allowed to happen.

Even as the president of the college and Sir Richard were making their brief speeches, just a few miles away public relations experts were starting another day's work to make people think that one of the world's biggest tobacco firms has now reformed and is socially responsible, and that its chief executive is a skilled and caring member of society, fit for public honour and possibly for further, high profile appointment in British public life.

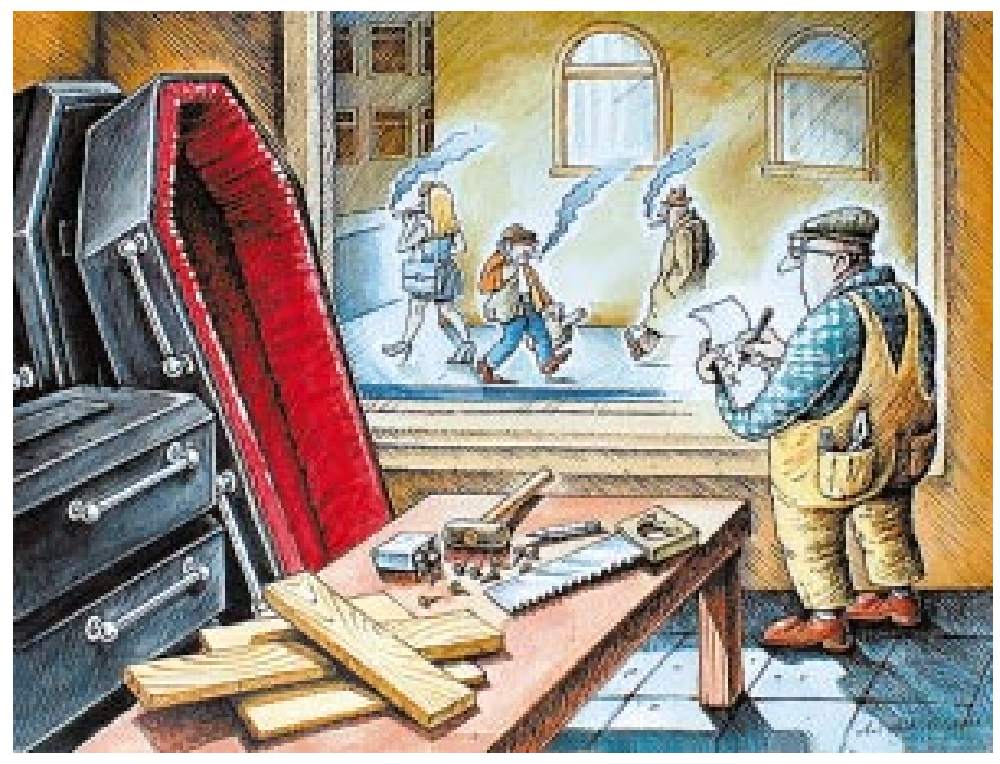

Ali Shahali from Iran won first place in the World's Fastest Clown 2001 international cartoon competition with his cartoon. The competition aimed to reflect the dangers of tobacco and attracted entries from 47 countries. View the other finalists at www.worldsfastestclown.com/ finalist.html 